Available online at www.jmle.org

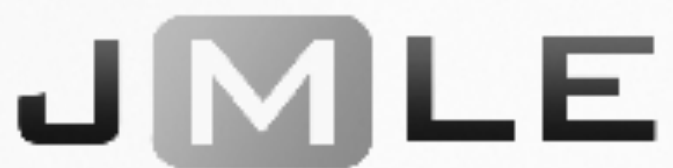

The National Association for Media Literacy Education's

Journal of Media Literacy Education 10 (2), 53 - 85

\title{
Winning the War on State-Sponsored Propaganda: Results from an Impact Study of a Ukrainian News Media and Information Literacy Program
}

\author{
Erin Murrock, Joy Amulya, Mehri Druckman and Tetiana Liubyva \\ International Research and Exchanges Board
}

From 2015-2016, IREX implemented a media literacy training program called Learn to Discern (L2D) that trained Ukrainian citizens to critically assess news media messages and identify misinformation. In 2017, IREX conducted a quasi-experimental impact evaluation in a stratified random sample of L2D participants and a control group $(n=412)$ matched for gender, age, region and education levels. A news literacy assessment was administered under two scenarios: an objective news article and a disinformation-based news article that included a series of questions to assess media analysis skills, knowledge of the news media environment and Media Locus of Control. Results show statistically significant higher levels of news analysis skills and knowledge of the news media environment for L2D participants, controlling for geographic region, education level, age, and gender. The results also found that news media behaviors acquired during the training persisted over a year following the training. In both groups, those who had a better ability to correctly identify disinformation also had better knowledge of how news media works, and slightly greater sense of control (assessed as Media Locus of Control) over their media choices. Future news media literacy programs should balance identifying and evaluating objective news stories and disinformation to ensure individuals are truly media literate in today's news media environment.

Keywords: News media literacy, media literacy, disinformation, media and information literacy, impact evaluation, assessment, Ukraine

An emerging threat to the news media is the rise of fake news and disinformation campaigns to destabilize democracies (Zakem, 2017). In recent years, Ukraine has seen an increase in disinformation and propaganda to disturb democratic progress since the 2014 Ukrainian revolution. Half-truths and alternative facts from Kremlin-funded media sow fear and 
confusion about news events, creating "uncertainty, confusion, and ultimately a doubt whether any source can be trusted without personal experience" (Nimmo, 2015, p.5). To address this issue, IREX (International Research and Exchanges Board), an international development nongovernmental organization, backed by funding from the Canadian government and the support of local Ukrainian organizations, implemented a nine-month media literacy training course called Learn to Discern (L2D), training more than 15,000 Ukrainians to think more critically about how they consume media in order to question misleading news (IREX, Learn to Discern, 2016). Through skills-based workshops focused on changing news media consumption behavior, 361 citizen trainers from across the country, representing a broad range of age groups, educational, and occupational backgrounds, delivered the L2D training via their social networks in schools, workplaces, and communities.

In contrast to more traditional media literacy courses, the L2D training specifically focused on teaching citizens to identify markers of manipulation and disinformation in the news media. The curriculum intended to foster critical thinking skills, teaching participants not only how to select and process news, but to also discern what not to consume. The training was adapted by citizen trainers to the needs and interests of their workplace or community networks and was reported by participants to last between several hours up to more than eight hours. The majority of participants reported receiving about a half day of training total. An exit survey of participants verified that all of the topics in the curriculum were covered. Results from the L2D program evaluation showed that participants reported gaining a deeper appreciation of, and greater skills in, what is needed to consume news wisely. The percentage of participants who reported cross-checking the news was $82 \%$ of those surveyed after the training, in contrast to $60 \%$ of those surveyed at the beginning of the training. In addition, ratings of confidence in analyzing the truthfulness of media content and for distinguishing true from false news were $30 \%$ higher for end-of-training survey respondents compared to pre-training survey respondents. A large majority ( $80-90 \%)$ of participants surveyed a month after the training reported using the news media literacy behaviors taught in the training: cross-checking news, looking for facts, and checking the source.

In 2017, IREX sought to evaluate the long-term impacts of the L2D training by assessing news media literacy skills and knowledge in a stratified random sample of L2D participants and comparing the results to those for a control group matched for gender, age, region and education levels. The goal of the impact evaluation was to assess the extent to which L2D participants were able to demonstrate the skills and knowledge targeted by the L2D curriculum and whether their ability to demonstrate these skills and knowledge was better than a comparison group matched on gender, education, age, and geographic region who had not taken the training. Here we describe the evaluation study and present key findings and contributions from the research.

\section{LITERATURE REVIEW}

This evaluation of the long-term effects of L2D is grounded within the literature of media literacy education and news media literacy. Work from these fields was used to inform the development of a news media literacy assessment aligned to the skills and knowledge delivered through the L2D training. 


\section{Media Literacy}

Aqili and Nasiri (2010) defined media literacy as "the way people analyze and interpret messages from mass media" (p. 452). Aufderheide and Firestone (1993) define media literacy as "the ability to access, analyze, evaluate and communicate messages in a wide variety of forms" (Aufderheide \& Firestone, 1993), emphasizing the skills of analyzing, evaluating, and creating media and technology messages (Masterman, 1985; Messaris, 1994). Hobbs and Frost (2003) emphasized the importance of asking questions related to critically engaging with the media and considering the intent of the media message, who is sending the message, what techniques are used to deliver the message and attract attention. Hobbs and Frost (2003) conducted a randomized control experiment to measure critical media analysis skills in a media literacy curriculum embedded in a yearlong 11th grade English media and communications course and compared results with a demographically similar control group. The researchers administered a media literacy assessment at the start and end of the year with the treatment and control groups. The assessment included questions addressing the following components of media literacy skill, as shown in Table 1.

\section{Table 1}

Components of Media Literacy Skill (Hobbs and Frost, 2003)

\begin{tabular}{|l|l|}
\hline CONCEPT & OPERATIONALIZATION \\
\hline Construction techniques & Recognize and describe how media messages are constructed \\
\hline Point of view & Identify point of view in a media message \\
\hline Omissions & $\begin{array}{l}\text { Recognize information that was omitted in an informational } \\
\text { message }\end{array}$ \\
\hline Compare and contrast & $\begin{array}{l}\text { Compare and contrast messages from different types of news } \\
\text { programs, e.g., local and national news }\end{array}$ \\
\hline Purpose & Identify the purpose of a media message \\
\hline Target audience & Identify the intended audience of a media message \\
\hline
\end{tabular}

The researchers found that the students who received the media literacy curriculum showed statistically significant greater gains in their ability to identify construction techniques, point of view, omitted information, comparison-contrast, and message purpose. The researchers concluded that the students who received the media literacy instruction were more likely to "recognize the complex blurring of information, entertainment and economics that are present in contemporary nonfiction media" (Hobbs \& Frost, 2003, p. 351). The L2D curriculum taught participants how to analyze and evaluate media messages using a similar set of categories. Thus the assessment developed by Hobbs \& Frost was adapted for use in the L2D evaluation (our assessment is described in more detail below). 


\section{News Media Literacy}

News media is a sub-area of media literacy focused on using existing examples of journalism to teach actionable skepticism in the form of journalistic verification skills (Fleming, 2014). This includes skills for analyzing news articles as well as knowledge of "media knowledge structures." People with knowledge of how the news media industry is structured and operates "are much more aware during the information-processing tasks and are, therefore, more able to make better decisions about seeking out information, working with that information, and constructing meaning from it that will be useful to serve their own goals" (Potter, 2004, p. 69).

Maksl, Ashley and Craft (2015) developed a news media literacy scale with three subscales, as shown in Table 2. They examined relationships among scores on each subscale in a sample of 500 teenagers ages 14 to 17 living in a large metropolitan area. They found that scores on the three subscales could be used to differentiate between a highly news literate group and a less news literate group. Highly news literate teens were more motivated to consume news, more skeptical of news media, and more knowledgeable about current events, although they did not consume more news media than their less news media literate peers. In a subsequent study to better understand outcomes from a news media literacy course, Maksl, Craft, Ashley and Miller (2017) found that students who had taken the course showed increases in news media literacy scores, motivation for news consumption, and knowledge about current events compared to a control group that did not take the course. ${ }^{1}$

\section{Table 2}

Components of News Media Literacy Skill (Maksl, Ashley and Craft, 2015)

\begin{tabular}{|l|l|}
\hline CONCEPT & OPERATIONALIZATION \\
\hline $\begin{array}{l}\text { Media Knowledge } \\
\text { Structures }\end{array}$ & $\begin{array}{l}\text { Understanding of knowledge structures related to the news } \\
\text { media industry (e.g., ownership media outlets, who has the most } \\
\text { influence of what gets aired on local TV news) }\end{array}$ \\
\hline Need for Cognition & $\begin{array}{l}\text { Preference for mindful versus automatic thought-processing of } \\
\text { news } \\
\text { depth about pomething) }\end{array}$ \\
\hline Media Locus of Control & $\begin{array}{l}\text { Degree of perceived control of whether and how one is } \\
\text { influenced by media }{ }^{3} \text { (e.g., can avoid being misinformed by } \\
\text { paying attention to different sources of news) }\end{array}$ \\
\hline
\end{tabular}

\footnotetext{
${ }^{1}$ The following assessments were administered: Need for Cognition Scale (the degree to which one engages in mindful versus automatic thought-processing of news); Media Locus of Control (the degree to which one perceives oneself as being in control of whether and how news media influences); News Media Knowledge Structures (focused on Potter's 2004 "knowledge structures": institutions that produce news, the way in which the content of the news is produced, and the awareness of possible effects of that content on people); Intrinsic Motivation for News consumption; News Media Skepticism; News Media Use; and Current Events Knowledge.

2 Adapted from the Need for Cognition scale developed by Epstein et al., 1996.

${ }^{3}$ Adapted from a scale measuring the extent to which an individual feels they are in control of their own health (Wallston \& Strudler Wallston, 1978).
} 
Additional research at the Center of News Literacy at Stony Brook University sought to identify tasks that could be used to measure the extent to which students who have taken a news literacy course are better able to differentiate between higher quality and lower quality news content compared to a control group. The tasks used for the assessment included differentiating between a reliable and less-reliable source, whether a story includes or excludes links that would allow the respondent to fact check, and whether a source has a vested interest in an event being reported (Weber, 2012). In most of the tasks, the news literacy students were better able to deconstruct the stories, but in some cases, were comparable to the control group. The researchers found that in general, the differences between the news literacy students and the control group waned after one year. Out of the three components of news media literacy skill shown in Table 2, the L2D curriculum was aimed at addressing knowledge structures related to the news media and how individuals can avoid being misinformed by checking multiple news sources.

\section{Review of the Learn to Discern Curriculum}

While many topics covered in the L2D curriculum were similar to those found in the news literacy literature, the L2D program tackled issues that were specific to the news media environment in Ukraine, going beyond deconstructing how the media creates messages to being able to recognize deliberate efforts to manipulate people and public opinion through misleading headlines and emotionally manipulative content. The program team was careful to consider neutrality of sources and to not endorse any type of media outlets to mitigate against any antiRussian or anti-Western bias. The L2D curriculum taught individuals to discern disinformation tactics, more fully understand the news media environment, use specific questions to reflect on whether a news item meets the basic journalism standards of quality, and understand markers of manipulation and disinformation in the media, including emotional manipulation tactics. For example, the curriculum included an exercise that asked participants to identify audience, purposes, techniques used to attract attention or solicit an emotional response, and what type of information was presented and omitted. The curriculum also covered types of propaganda, types of media, media owners in Ukraine, and the concepts of trust, credibility, objectivity and media ownerships and their potential effects on what news is presented.

The curriculum consists of three chapters. The first chapter provides participants with a basic understanding of information and propaganda. It gives an overview of the types of mass media, their work, objectivity, and media ownership. The second chapter covers manipulation, fake news, and propaganda and their dangers. Through practical exercises, participants gain experience analyzing media content (headlines, texts, pictures, and videos) using debunking tools and identifying markers of fakes, manipulation, and propaganda. The third chapter explores the consequences of dehumanization, stereotypes, and hate speech in the media. All material is written in a simple, easy-to-understand way and contains numerous examples, exercises, and handouts that help participants not only to learn, but also to share the information with friends and relatives.

The L2D curriculum includes an assessment exercise asking participants to identify audience, purposes, techniques used to attract attention or solicit an emotional response and what type of information it presents and omits, similar to the critical thinking questions used by Arke and Primack (2009) and Hobbs and Frost (2003). The L2D curriculum covered types of propaganda, types of media, media owners in Ukraine, and the concepts of trust, credibility, objectivity, and media ownership and its potential effects on what news is presented. These areas overlap considerably with the news media knowledge structures included in the News Media 
Literacy Scale used by Maksl et al. (2017) as well as Weber's (2002) approach to asking participants to judge the credibility of sources used in the news articles. This close alignment with existing assessment approaches led to the adaptation of several of them for the L2D evaluation.

\section{Development of the L2D Assessment}

The L2D assessment had three components. The first was a two-part news media analysis assessment using the media literacy skill components identified by Hobbs \& Frost (2003) and Weber (2012). The first part of the media analysis assessment used an objective news article (about a shooting at the Ukraine-Russia border) while the second used an article based on disinformation and manipulation (about educational reforms in Ukrainian schools that would remove minority languages in schools (such as Russian). The second component was an assessment of news media knowledge structures, adapted from Maksl, Ashley and Craft (2015) to evaluate knowledge of media outlet ownership, the way in which the content of the news is produced, and awareness of effects of ownership and content production on how news is reported. The third component of the assessment examined the respondent's sense of control over how they are influenced and informed by the news, using the media locus of control assessment developed by Maksl, Ashley and Craft (2015). Appendix A summarizes the sources for each component of the L2D assessment and any validation studies conducted on the assessment measures. Appendix B includes the assessment instrument used in the evaluation.

\section{METHOD}

\section{Research Question}

The primary research question for the impact study was: Do L2D participants have better news media literacy skills than the general population 1.5 years after the end of the program? We hypothesized:

H1: L2D participants will outperform the control group in objective news media analysis.

H2: L2D participants will outperform the control group in disinformation news media analysis.

H3: L2D participants will outperform the control group in news media knowledge.

H4: L2D participants will have higher Media Locus of Control scores than the control group.

\section{Instrument}

The survey instrument was piloted with 33 L2D participants and nonparticipants to evaluate clarity, length, and interest. Following the pilot test, the survey was revised and deployed to the L2D and comparison group samples. The survey instrument assessed five areas: objective news analysis skill; disinformation news analysis skills; news media knowledge, media locus of control; and self-rating of awareness of disinformation, news media analysis skills, news media consumption behavior, trust, and value of objective news. L2D participants were also asked to rate their level of their skills, confidence, and news media consumption behavior before the training, as well as whether they had transferred the information from the L2D training to friends, relatives, or colleagues. Scores for each of the assessments were calculated based on 
adding up the points for each "correct" (i.e., news media literate) answer to the questions in each section and standardized to a 100-point scale. Table 3 shows the components of the survey. The complete survey is available for review at the JMLE homepage for this research study.

Table 3

\section{Concepts Covered by L2D Impact Study Survey Instrument}

\begin{tabular}{|l|l|}
\hline CONCEPTS & COMPONENTS \\
\hline Demographic data & Gender, age, geographic region, education, occupation \\
\hline $\begin{array}{l}\text { Objective news media } \\
\text { assessment }\end{array}$ & Analysis of an objective news story \\
\hline $\begin{array}{l}\text { Disinformation news medi } \\
\text { assessment }\end{array}$ & Analysis of a news story based on false and manipulative informatio \\
\hline $\begin{array}{l}\text { News media knowledge } \\
\text { assessment }\end{array}$ & Knowledge of media structures and ownership \\
\hline $\begin{array}{l}\text { Media locus of control } \\
\text { assessment }\end{array}$ & Sense of control over the influence of media \\
\hline $\begin{array}{l}\text { Self-rating questions } \\
\text { Awareness of disinformation, news media analysis skills, news } \\
\text { media consumption behavior, trust, and value of objective news. } \\
\text { L2D participants: self-rating of skills, confidence, and news media } \\
\text { consumption behavior before the training; transfer of information } \\
\text { to others }\end{array}$ \\
\hline
\end{tabular}

\section{Sample}

We aimed to reach a target sample size of 200 Ukrainian adults for the treatment and control group in order to achieve the desired statistical power of $80 \%$. A disproportionate stratified random sampling method was used to ensure that the control group sample represented the same education levels, gender, and geographic regions present in the L2D participant population. With disproportionate stratification, the sample size of each stratum does not have to be proportionate to the population size of the stratum. This was done so that less frequent subgroups were adequately represented in the sample. A total 412 individuals completed the survey (207 L2D participants and 205 non-participants). Gender, age, and education levels were balanced across both groups. 39\% were people ages 18-30 years old, 42\% were between 31 and 55 years old, and $19 \%$ were age 56 or older. Forty-one percent were from the Central region, $23 \%$ were from the Eastern region, and 35\% were from the Southern region. Thirty-four percent had completed secondary or vocational school, while $66 \%$ had completed higher education.

\section{RESULTS}

People who participated in the L2D training outperformed the control group on three out of four news media literacy assessment areas. To determine whether L2D participants had better news media literacy skills than a similar group of non-participants ( $\mathrm{H} 1$ and H2), we conducted an initial analysis of variance to test the difference between group means on each assessment. The ANOVA results showed that the L2D group scores were higher for the disinformation news media analysis assessment $(F(1,410)=8.56, p<.001)$ and the news media 
knowledge assessment $(\mathrm{F}(1,410)=51.26, \mathrm{p}<.0001)$, but not for the objective news media analysis or media locus of control, leading us to conclude that $\mathrm{H} 2$ and $\mathrm{H} 3$ is supported, but not H1 or H4. As Table 4 shows, these results allow us to conclude that Learn to Discern participants had better skills in analyzing disinformation news and higher levels of knowledge of the news media system compared to the general population, even 1.5 years after the end of the training.

\section{Table 4}

\section{Mean Scores for News Media Assessment Areas}

\begin{tabular}{lllll}
\hline & $\begin{array}{c}\text { Objective } \\
\text { News media } \\
\text { Analysis }\end{array}$ & $\begin{array}{c}\text { Disinformation } \\
\text { News Media } \\
\text { Analysis }\end{array}$ & $\begin{array}{c}\text { News Media } \\
\text { Knowledge }\end{array}$ & $\begin{array}{c}\text { Media Locus of } \\
\text { Control }\end{array}$ \\
\hline Control $(\mathrm{n}=205)$ & 4.43 & 7.35 & 12.87 & 3.50 \\
L2D $(\mathrm{n}=207)$ & 4.15 & $8.23^{* *}$ & $16.53^{* *}$ & 3.64 \\
\hline
\end{tabular}

$* * \mathrm{p}<.0001$

Although the mean scores for media locus of control for the L2D group were higher, there was not a statistically significant difference between the two groups. An additional analysis was conducted to determine if there were differences between the two groups in the individual media locus of control items. The results showed that there were statistically significant differences for two particular items: "When I am misinformed by the news media, I can do something about it" $(\mathrm{F}(1,356)=7.26, \mathrm{p}<0.01)$ and "If I pay attention to multiple sources of information, I can avoid being misinformed." $(\mathrm{F}(1,388)=3.87, \mathrm{p}=0.05)$. For these two dimensions of the locus of control measure, L2D participants perceived themselves to be more in control of how they are influenced by news media.

Although the L2D and control samples were similar in gender, age, geographic location, and level of education, the results were checked using multiple regression analysis to control for these demographic variables. The regression analysis results found that L2D participant scores on the disinformation news media assessment were 13\% higher than the non-participant group, and $28 \%$ higher on the news media knowledge assessment, controlling for gender, age, geographic location, and level of education. Compared to the control group, L2D participants had better disinformation news media analysis skills and more knowledge of the news media environment compared to the general population a year and a half after the end of the training. L2D participants also had a slightly greater sense of control over how they are influenced by the media as measured by media locus of control. Figure 1 illustrates the relative gap between L2D participants and the control group in each area.

Both groups scored lower for the objective news analysis than the other assessment areas, suggesting that detecting markers of objective news may be more difficult than detecting manipulation and disinformation, and that analysis of objective news was not emphasized as much in the training. ${ }^{4}$ The fact that this was the only area for which there was not a statistically significant difference between L2D participants and the control group when education level, geographic region, age, and gender are taken into account suggests that skill for analyzing

\footnotetext{
4 The disinformation news story followed the objective news story on the survey, so lower scores on the analysis of the objective story cannot be attributed to an influence of being more critical on the disinformation story. Scores on the objective news analysis assessment ranged from 0 to $85 \%$ in both groups, and from 0 to $100 \%$ for the disinformation news analysis assessment.
} 
objective news needs to be developed on its own and that it likely needs to be coordinated with the skill for analyzing disinformation-based news. This is consistent with human development theory that shows skills that are developed in one context do not automatically transfer to new contexts, and when they are, must be coordinated with one another (Mascolo \& Fischer, 2010). However, another consideration was that the topic of the objective news story (a shooting on the Ukraine-Russia border) may have been especially sensitive due to the ongoing war in eastern Ukraine, causing both groups to be more hesitant in evaluating it for truthfulness.

The control group had lower knowledge of the news media environment compared to their ability to analyze the disinformation news story, whereas the L2D group had similar average scores in both areas. The fact that, even taking education level and other demographic factors into account, the control group had better scores on the disinformation news analysis assessment than on the objective news analysis assessment suggests there are additional factors that support the ability to detect misinformation. However, L2D training appears to result in stronger disinformation analysis skills, even a year and a half later.

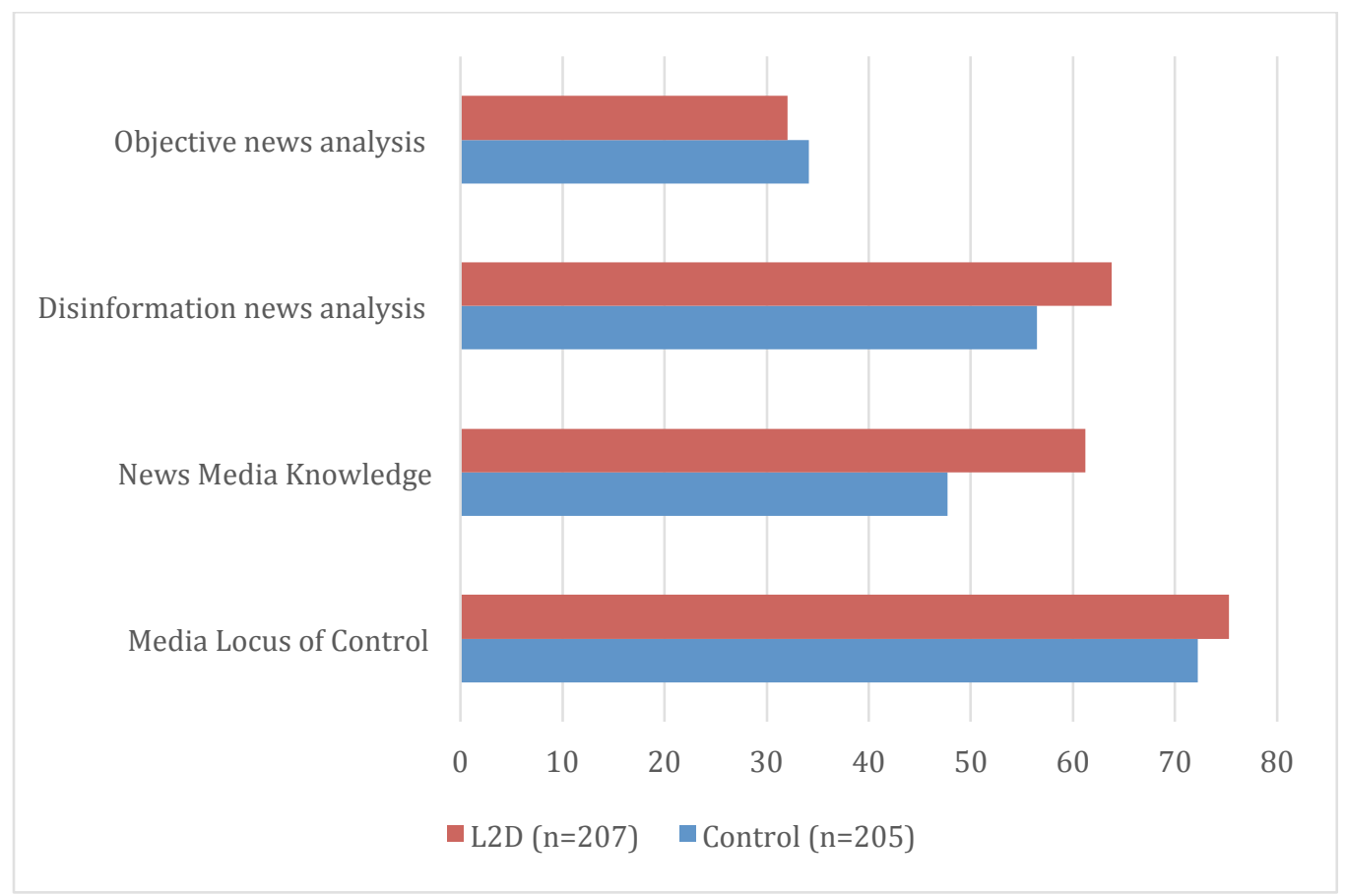

Figure 1. Comparison of L2D and control groups on each assessment area

The fact that both L2D participants and the control group scored above $70 \%$ on the media locus of control assessment suggests a fairly high sense of control in the adult population in Ukraine. However, when comparing control group and L2D participants, we found statistically significant differences on these items:

- When I am misinformed by the news media, I can do something about it

- If I pay attention multiple sources of information, I can avoid being misinformed

- If I take the right actions, I can stay informed 
These three items specifically addressed taking practical action to gain a greater sense of control over influence from the news media. The focus of the L2D curriculum was on providing the tools to discern objective news from false or manipulative news. This seems to translate into gains in a sense of control from putting those tools into action-which persists even a year and a half after the training.

In summary, L2D participants had better disinformation news media analysis skills and more knowledge of the news media environment compared to the general population a year and a half after the end of the training. L2D participants also had a slightly greater sense of control over how they are influenced by the media as measured by media locus of control. Both groups scored lower for the objective news analysis than the other assessment areas, suggesting that skill for analyzing objective news needs to be developed on its own and that it likely needs to be coordinated with the skill for analyzing disinformation-based news. Both groups had high scores on average on the media locus of control assessment, but L2D participants rated themselves higher in three areas related to taking practical action to gain a greater sense of control over influence from the news media.

L2D participants were more likely to cross-check other sources, rate their skills higher in distinguishing true information from false, and were more confident in their ability to analyze the truthfulness of media content compared to the control group. The survey asked respondents to rate their current skills and confidence in analyzing news media content, and to report their behavior in terms of cross-checking news through other sources. L2D participants were also asked to rate their skills, confidence, and behavior prior to the training. On average, L2D participants were $37 \%$ more confident in analyzing the truthfulness of media than the control group, and 38\% more likely to cross-check news in other sources. They also rated their skills in distinguishing true news from false news 30\% higher than the control group. Figure 2 shows these results, which show responses to each rating question standardized to a percentage scale, with $100 \%$ representing the highest score possible. The third and fourth questions were yes/no questions so the percentage scale represents the likelihood of a yes response.

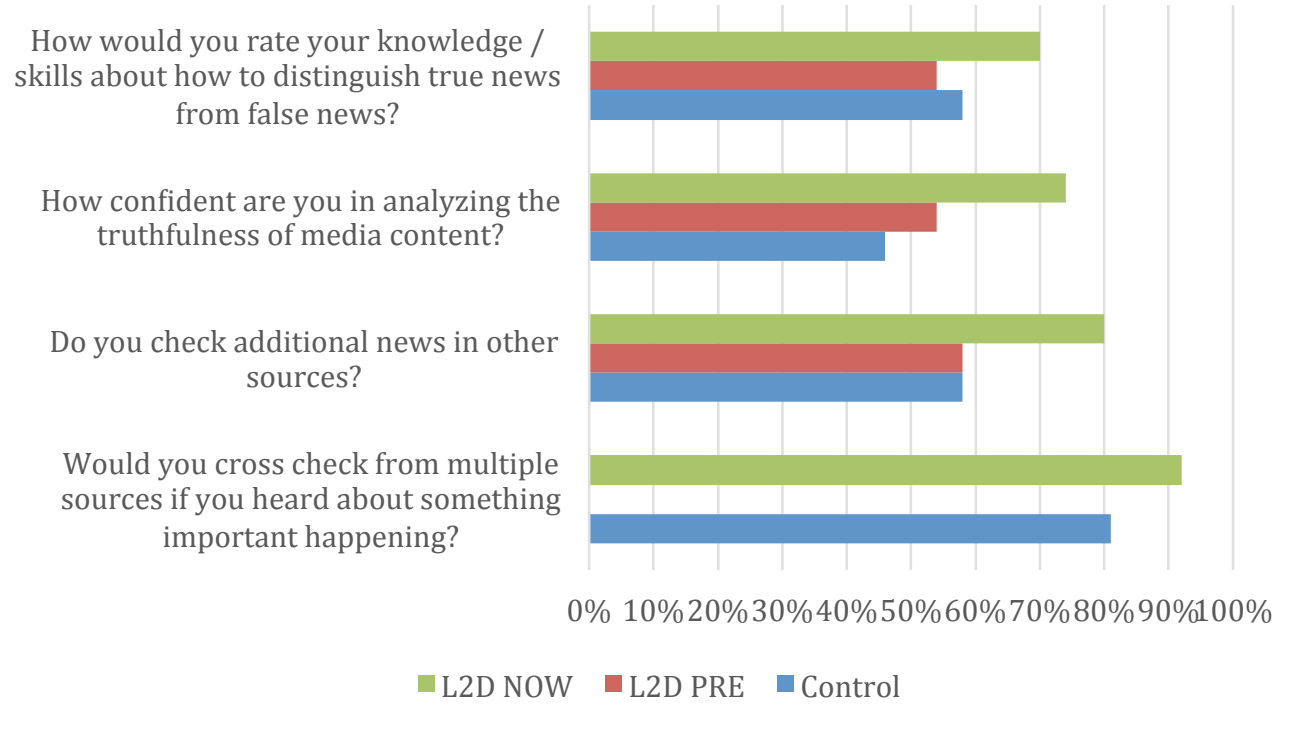


Figure 2. Comparison of self-ratings of news media skills, confidence, and behavi

Because there was no way to compare self-ratings in these areas to the ratings L2D participants gave themselves at the beginning of the training, we asked them to retrospectively rate their pre-training skills, confidence, and behavior. L2D participants were $61 \%$ more confident in their ability to analyze the truthfulness of media a year and a half after the training compared to before the training, 38\% more likely to cross-check news in other sources, and rated their skills in distinguishing true news from false news $21 \%$ higher. The control group was not asked to retrospectively rate their skills because they did not have a reference point to compare them to a year and half earlier.

L2D participants retained the behavior of cross-checking news a year and a half after completing the training. The impact study results found that $82 \%$ of L2D participants reported cross-checking the news, the same percentage found by the 2016 program evaluation for this behavior at the end of the training, as Table 5 below shows. Results from the 2016 L2D program evaluation had found that $60 \%$ of those surveyed at the beginning of the training. However only $32 \%$ of the L2D impact study group reported retrospectively that they cross-checked the news prior to the training. Retrospective pre-tests are often more valid self-assessments because participants are more familiar with a concept or procedure (e.g., the concept of "cross-checking") after they have taken the training (Gorrall, Curtis, Little \& Panko, 2016). Thus, we hypothesize that the retrospective pre-test level of $32 \%$ who cross-checked the news before the training may be a more valid estimate of pre-L2D behavior. However, it is possible that the validity gains in using retrospective pre-test scores may have been offset by the fact that participants were asked to rate their skills a year and a half after the training.

When retrospectively rating their ability to take the right actions to stay informed, they may rate themselves lower. The fact that $72 \%$ of the control group in the impact study reported that they cross-check the news is likely to be an overestimate due to their lack of familiarity with the procedure for crosschecking.

Table 5

Comparisons of Self-Reported Cross-Checking News Behavior

\begin{tabular}{|l|l|l|l|l|l|}
\hline & 2016 program evaluation & \multicolumn{2}{l|}{ 2017 Impact study } \\
\hline & Pre-test & Post-test & $\begin{array}{l}\text { L2D } \\
\text { retrospective } \\
\text { pre-test }\end{array}$ & $\begin{array}{l}\text { Control } \\
\text { group }\end{array}$ & $\begin{array}{l}\text { L2D 1.5-year } \\
\text { followup }\end{array}$ \\
\hline $\begin{array}{l}\text { Do you } \\
\text { crosscheck } \\
\text { the news? }\end{array}$ & $60 \%$ & $\mathbf{8 2 \%}$ & $32 \%$ & $72 \%$ & $\mathbf{8 2 \%}$ \\
\hline
\end{tabular}

Gains for L2D participants are greater when compared to retrospective pre-training ratings than compared to control group ratings. As described for cross-checking news above, the impact of the L2D training appears to be greater when the L2D ratings at the time of the year and a half follow-up are compared to retrospective ratings of pre-training skills instead of the control group. 
Table 6

Comparison of Gains in Self-Reported News Media Analysis Skill

\begin{tabular}{|l|l|l|}
\hline & $\begin{array}{l}\text { Comparison of L2D group } \\
1.5 \text {-year follow-up vs. control } \\
\text { group }\end{array}$ & $\begin{array}{l}\text { Comparison of L2D group } \\
1.5 \text {-year follow-up vs. } \\
\text { retrospective pre-training }\end{array}$ \\
\hline $\begin{array}{l}\text { Ability to analyze the } \\
\text { truthfulness of media content }\end{array}$ & $+37 \%$ & $+61 \%$ \\
\hline $\begin{array}{l}\text { Confidence in skills for } \\
\text { distinguishing true/false news }\end{array}$ & $+21 \%$ & $+30 \%$ \\
\hline
\end{tabular}

L2D participants rated their current skills $61 \%$ higher than their retrospective ratings for the ability to analyze the truthfulness of media content and $30 \%$ higher than their retrospective ratings of their confidence in their skills for distinguishing true news from false news. The analysis found that L2D participants' pre-training self-ratings and the control group's self-ratings were similar in for these two areas as well as for cross-checking news, as shown above. This supports the hypothesis that individuals rate themselves higher in these news media skill areas prior to being trained than they do afterward. Thus, the differences between L2D participants and the control group on skill self rating questions likely underestimates the actual difference between the two groups.

L2D participants retained high levels of news media skills and behaviors after one and a half years. The impact study survey asked L2D participants to rate their news media literacy skills and behaviors before the training and at the time of the one-and-a-half-year follow-up survey; however, it did not ask them to rate themselves after the training. In order to estimate the post-training levels, we used the 2016 L2D program evaluation one-month follow-up survey results. Because the L2D impact study sample was selected to be representative of the L2D participant population, the post-training results were used as an estimate of the average posttraining scores for the individuals in the L2D impact study sample. Scores for self-rated confidence and knowledge/skills were standardized to a 100 -point scale where $50 \%$ is neutral, $80 \%$ is confident/high, and $100 \%$ is very confident/high. Skills and behaviors remained steady or decreased only slightly after one and a half years. Figure 3 visualizes these key results. In the figure, retrospective pre-training scores are shown instead of those assessed prior to the training. Responses to each rating question were standardized to a percentage scale, with $100 \%$ representing the highest score possible. The news checking question was a yes/no question so the percentage scale represents the likelihood of a yes response.

Cross-checking news had the lowest levels prior to the training but improved immensely as a result of the training, and then remained steady as of the one-and-a-half-year follow-up survey. Confidence in analyzing the truthfulness of media content started at a moderate level $(54 \%)$, increased to $75 \%$ (a rating of "confident") after the training, and were about the same (74\%) after a year and a half. Similarly, self-rated skill in distinguishing true from false news also started at $54 \%$, increased to $76 \%$ following the training and decreased to $70 \%$ after a year and a half (less than 10\%). In contrast to other long-term follow-up of media literacy skills in the 
research literature (e.g., Weber, 2012), it does not appear that the skills acquired during the L2D training have waned after a year. ${ }^{5}$

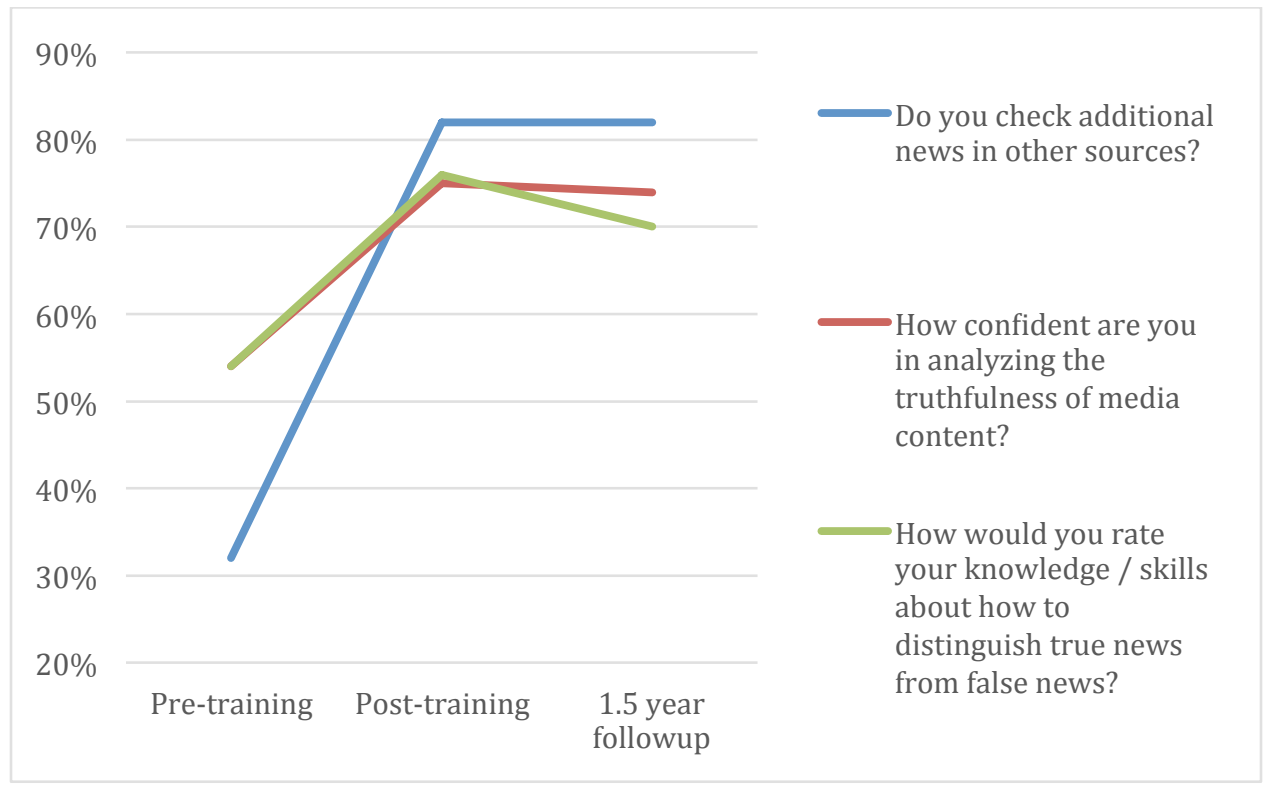

Figure 3. Estimated change in news media literacy skills and behavior

\section{L2D participants had a slightly greater awareness of paid-for materials presented as} though they were news but otherwise are similar to the control group in terms of trust, $T V$ ownership, and news consumption. Despite differences in news media skills and behaviors, L2D and control group respondents were similar in their levels of trust in the media (less than $50 \%$ ), reading/watching the news (80-85\%), and the importance of TV ownership (60-65\%). However, slightly more of the L2D participants who watch the news said they trust at least one news source. For the L2D group, of the $80 \%$ who watch the news, $55 \%$ trust at least one news source while $45 \%$ did not. For the control group, of the $86 \%$ who watch the news, $50 \%$ trust at least one news source while $50 \%$ did not. They were even similar in their awareness of paid-for materials presented as though they were news $(12 \%$ higher for L2D participants but this was not statistically significant) and in the importance of this issue (65-70\%). ${ }^{6}$ Figure 4 shows similarities between L2D participants and control group on general media-related survey questions. Responses were standardized to a percentage scale, with higher percentages representing either higher ratings or a higher likelihood of a yes response. As Figure 5 shows, the two groups also appeared to be similar in the extent to which they value, seek out, and are able to recognize quality journalism. However, L2D participants had consistent and statistically significant higher self-ratings in all three of these areas.

\footnotetext{
5 This finding is based on an estimate of the post-training ratings using responses from over 11,000 L2D participants. While the samples are similar, future evaluation of L2D trainees should build in a longitudinal follow-up design to better assess patterns of change over time.

6 The U-Media national survey on media consumption in Ukraine found a similar level of awareness of sponsored material, reporting that $55 \%$ of the population was aware about sponsored material in the media in 2017 (Internews, 2017).
} 
Issue of sponsored/ "paid for" materials in the media important for you

Aware of sponsored/ "paid for" materials presented in the form of news

Do you trust any news sources?

Do you read/watch news?

Ownership of TV is important to me.

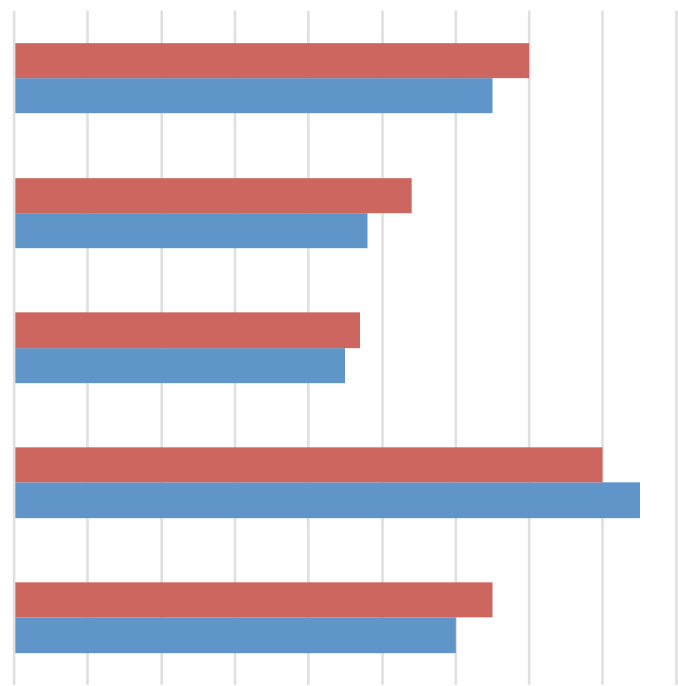

0\% $10 \%$ 20\% 30\% 40\% 50\% 60\% 70\% 80\% 90\%

- L2D Control

Figure 4. Similarities between L2D participants and control group on general media-related survey questions

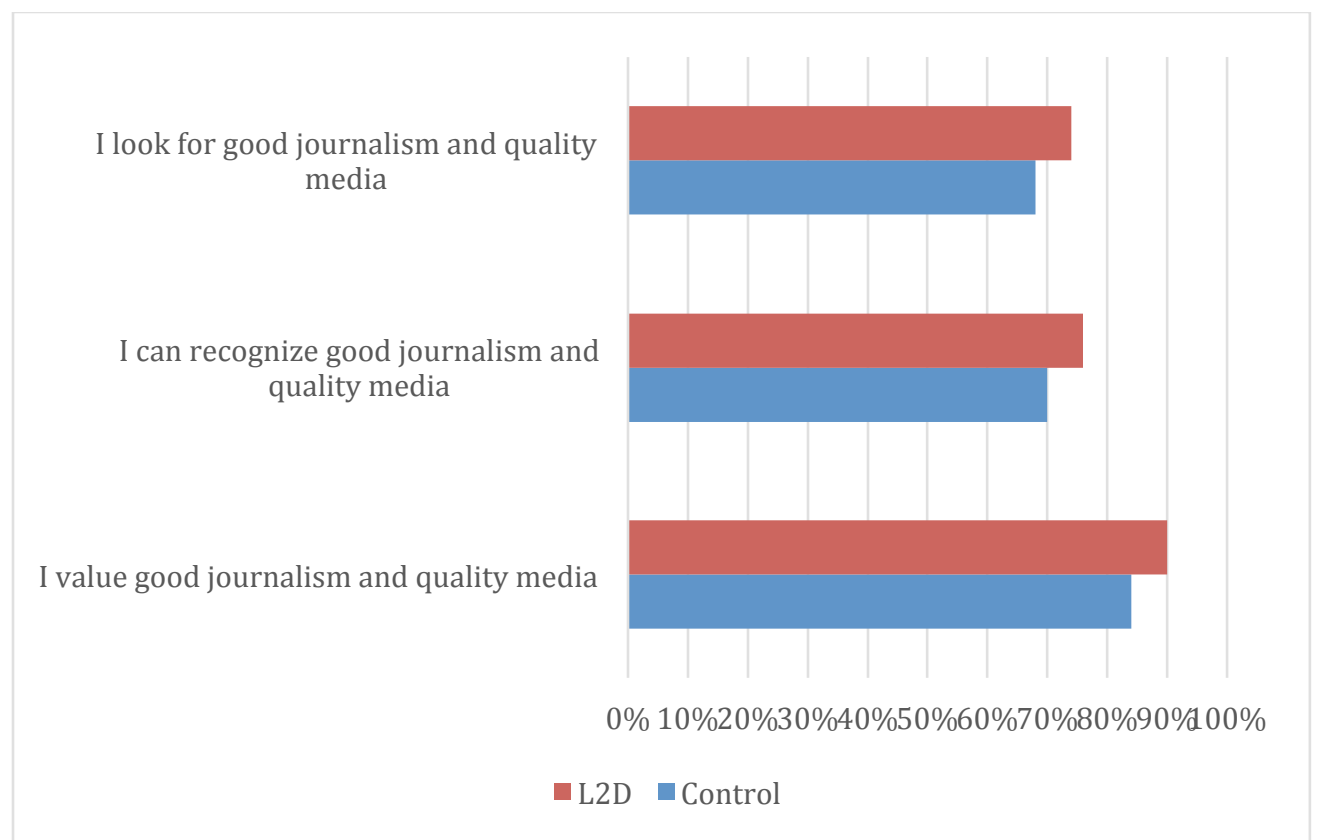

Figure 5. Comparison of L2D and control group on valuing, seeking, and recognizing quality journalism 
News media knowledge may mediate the relationship between media locus of control and disinformation analysis skill. In order to address the question of whether all of the news media literacy areas appear to be strongly related to one another, we examined the pattern of correlation for the four components of news media literacy in the L2D participant group and the control group. Table 7 summarizes our findings.

Scores on the objective news analysis assessment were not related to any of the other assessment areas in either group. In other words, those who scored higher on the objective news analysis did not tend to score higher on the disinformation news analysis, the news media knowledge assessment, or media locus of control assessment. The strongest relationship in both groups was between disinformation news analysis and news media knowledge; those with higher scores on one tended to have higher scores on the other. This tracks with the finding that understanding news media knowledge and preference for mindful vs. automatic thinking are both characteristics of high news literate individuals (Maksl, Ashley \& Craft, 2015). The strongest relationship with media locus of control was with news media knowledge and not with disinformation news analysis skill. We hypothesize that news media knowledge-understanding who owns media outlets and how ownership may influence news content production-may mediate the relationship between media locus of control and disinformation analysis skill. By gaining knowledge about the structures through which news is generated, the necessity for disinformation news analysis skills becomes clear. At the same time, a sense of control over choices about media consumption might be enhanced by a greater understanding of the structures through which news is generated.

Table 7

Strength of Relationships among Components of News Media Literacy

\begin{tabular}{|c|c|c|c|}
\hline & $\begin{array}{c}\text { Objective news } \\
\text { analysis }\end{array}$ & $\begin{array}{c}\text { Disinformation } \\
\text { news analysis }\end{array}$ & $\begin{array}{c}\text { News media } \\
\text { knowledge }\end{array}$ \\
\hline $\begin{array}{c}\text { Disinformation news } \\
\text { analysis }\end{array}$ & None & & \\
\hline $\begin{array}{c}\text { News media } \\
\text { knowledge }\end{array}$ & None & $\begin{array}{c}\text { Strong } \\
\text { L2D }>\text { control } *\end{array}$ & Low** \\
\hline $\begin{array}{c}\text { Media locus of } \\
\text { control }\end{array}$ & None & $\begin{array}{c}\text { Moderate } \\
\text { L2D }>\text { control*** }\end{array}$ \\
\hline
\end{tabular}

$*$ Disinformation news analysis vs. News media knowledge correlation: L2D participants $\mathrm{r}=.55$, control group $\mathrm{r}=.50$.

** Disinformation news analysis vs. Media locus of control: L2D participants $\mathrm{r}=.18$; control $\mathrm{r}=.17$.

*** News media knowledge vs. Media locus of control: L2D participants $\mathrm{r}=.36$, control group $\mathrm{r}=.30$.

Higher education is the strongest predictor of all areas of news media literacy except media locus of control, but age, gender and geographic region are also factors. Educational background was strongly related to respondents' objective news analysis skill, disinformation news analysis skill, and news media knowledge but not media locus of control. Surprisingly, media locus of control scores were similar across the three education subgroups. Respondents with higher levels of education tended to have higher scores on the disinformation news analysis and news media knowledge, which may be related to having had more opportunities to develop 
critical thinking skills. As Figure 6 shows, the reverse was true for the objective news analysis: higher levels of education were related to lower scores. Critical thinking may be related to skepticism, causing higher-educated, more critical thinking individuals to be skeptical of objective news (particularly when asked to analyze it) (Garrison, 1992).

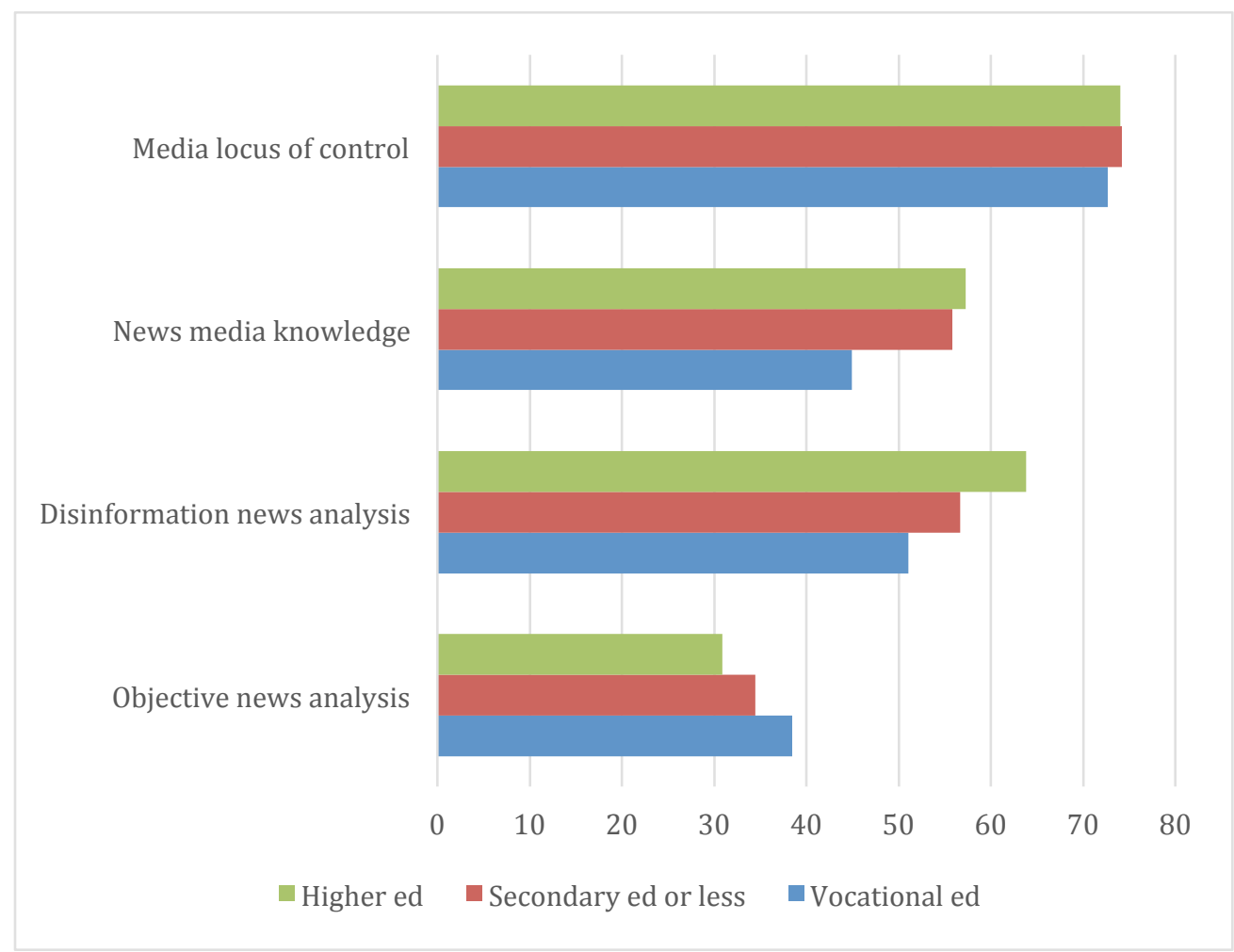

Figure 6. Average media literacy scores by education group

Age differences were also important, and they were related strongly to scores on the objective news analysis as well as the disinformation news analysis. However, it was the youngest age group that had the highest scores on the objective news analysis (they were low relative to that group's disinformation analysis scores). That trend reversed itself for the disinformation news analysis assessment: the older age groups - particularly 31-55-tended to score higher than the youngest age group. As Figure 6 shows, the 31-55 age group was more likely to have a higher education background, while the 18-30 age group was more likely to have a secondary education or less. Those with a vocational education were balanced across age groups. Age was not related to either news media knowledge or media locus of control. 


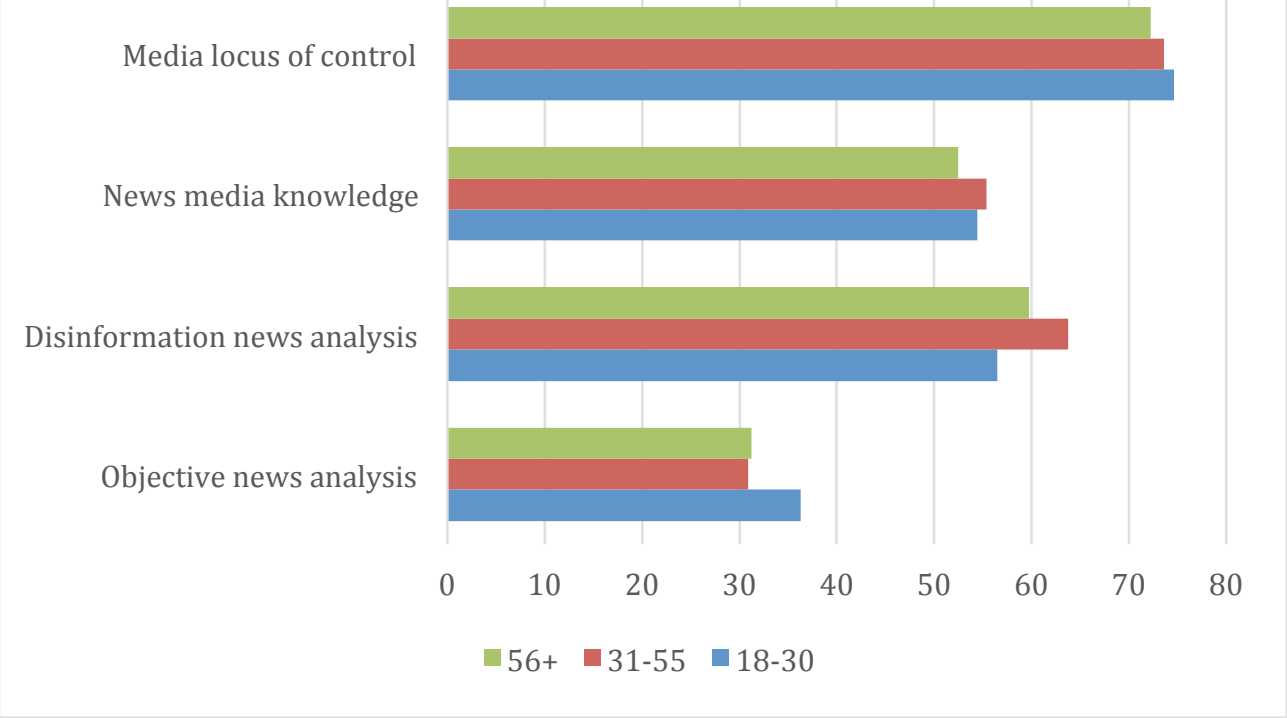

Figure 7. Average media literacy scores by age group

Region was also related to news media literacy, with higher scores on the disinformation news analysis and news media knowledge for those from the Central region. Respondents from the Eastern region had the next highest news media knowledge while those from the Southern region had the second highest disinformation news analysis scores on average. Like age and education, region was also not related to media locus of control.

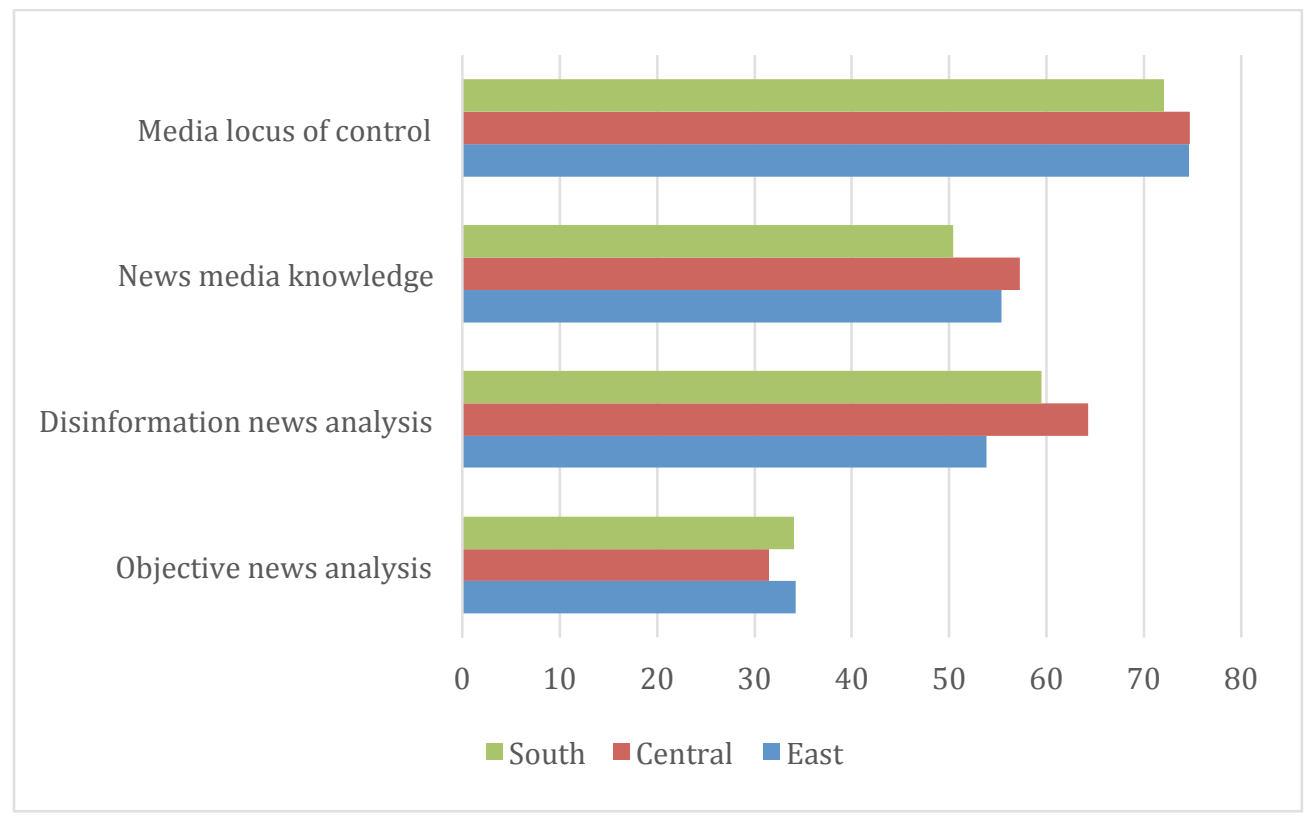

Figure 8. Average media literacy scores by region 
Finally, the only area for which gender was a factor was news media knowledge. Male respondents tended to have somewhat higher scores compared to females. There were no significant differences for any of the other news media areas.

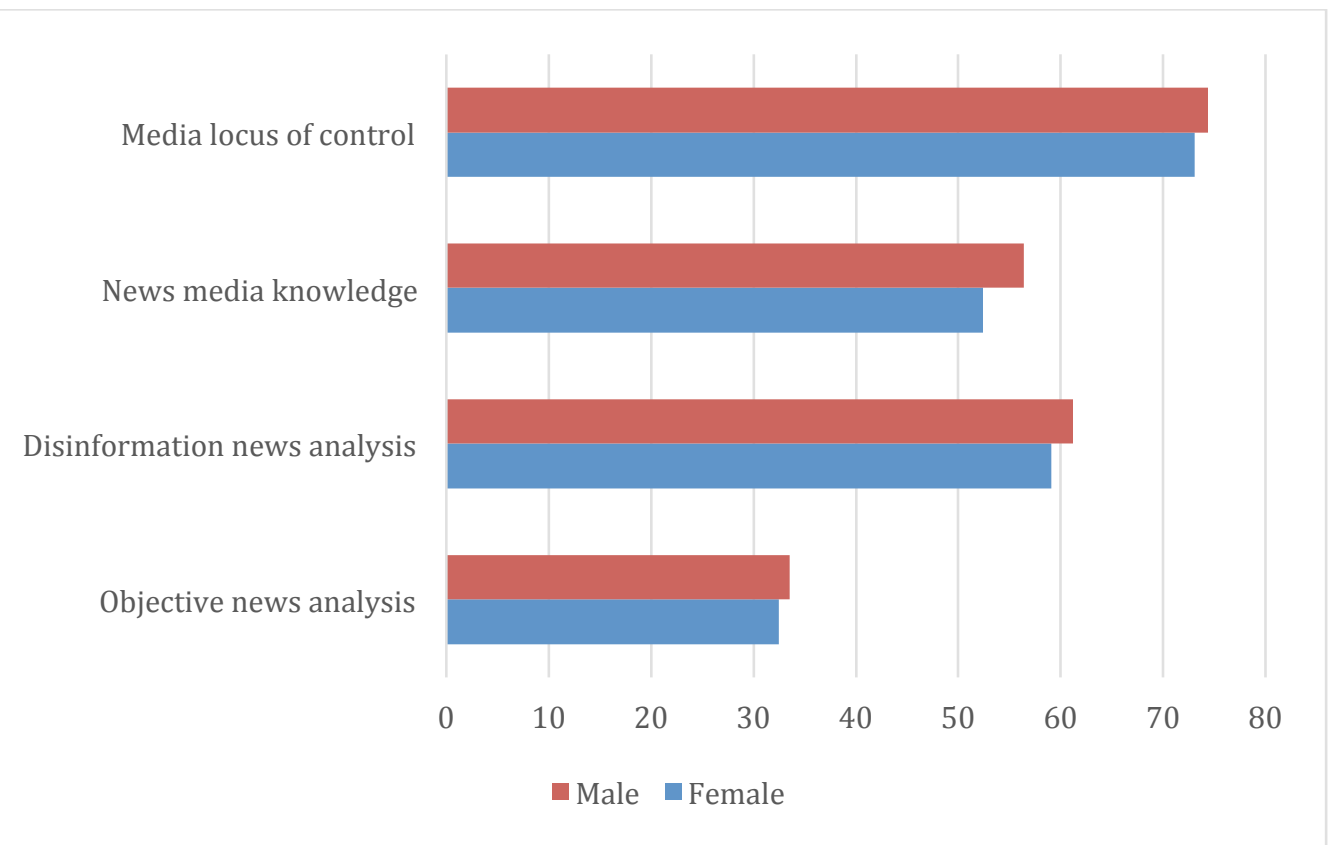

Figure 9. Average media literacy scores by gender

\section{DISCUSSION}

Analysis of objective news vs. disinformation. L2D participants clearly outscored nonparticipants on analysis of the news story that was based on disinformation. Although we had hypothesized that individuals who participated in the Learn to Discern training would be better than the non-participant in analyzing both objective and disinformation news media stories, there was not a statistically significant difference between the L2D and control groups on the objective news media assessment; however, there was a slight trend toward lower scores for the L2D group. Despite the neutral headline and language used in the article, the story topic was of an emotional nature and could have led to L2D participants to be more skeptical of its objectivity. The study by Maksl, Ashley and Craft(2015) found that more news literate teens were more skeptical of news media than those in the low news media literacy group. Thus, the lack of differences between the L2D and control groups on the objective news media assessment could be interpreted as a natural consequence of greater skepticism by those who are more news media literate. This may be the result of the fact that the L2D training emphasized deconstructing deliberately manipulative news stories rather than discerning the markers of more objective news reporting. Mihailidis $(2009,19)$ asserts that teaching critical thinking alone is not sufficient for news media literacy; without acknowledging the news media's role in democracy, media literacy education could "run the risk of breeding cynical dispositions rather than nuanced understandings of [its] role." 
Further research examining news media literacy trainings that explicitly address the positive role of media in society as well as media consumers role in civic participation would provide important insight into whether the independent variable of the L2D training affected the skepticism on objective news stories. Only one other study in the literature (Hobbs \& Frost, 2003) compared scores on objective news and found that the experimental group scored higher than the control group; no other studies have asked participants to distinguish between objective news and disinformation. Kahne and Bowyer (2017) did find that exposure to media literacy training, even if limited, impacted their survey participants' abilities to analyze news and misinformation sources as well as reduced the effects of motivated reasoning, or selecting evidence from information sources to support existing beliefs.

Retention of news media knowledge and behaviors over time. In contrast to other follow-up of media literacy skills in the research literature (e.g., Weber, 2012), the skills acquired during the L2D training were retained after a year and a half. This finding is based on an estimate of the post-training ratings using responses from over 11,000 L2D participants. While the samples are similar, future evaluation of L2D trainees should build in a longitudinal follow-up design to better assess patterns of change over time.

A large majority $(82 \%)$ of L2D participants retained the behavior of cross-checking news a year and a half after completing the training, and only slight declines were found for skill in distinguishing true from false news and confidence in analyzing the truthfulness of media content. This could be due to the delivery of the training through social networks, which have the potential to reinforce news media literacy skills and behaviors (Sucala, 2018). The L2D curriculum had a number of differences from other types of news media training in that it focused on changes in behavior, not just gaining knowledge and skills. In addition, the L2D training was focused on news media literacy and was context-specific, addressing media consumption habits and targeting specific media and information issues in Ukraine at the time of the training.

Finally, it was designed to raise healthy skepticism in those who were not currently the audience of fact-checked news and information. By ensuring that participants felt the need to acquire news-checking and other news literacy skills, the training appears to have led to greater retention. ${ }^{7}$ A large majority $(90 \%)$ of $\mathrm{L} 2 \mathrm{D}$ participants surveyed after the training reported sharing information from the training with other people, which is equivalent to an average of six people per trainee. Research on learning shows that teaching others supports learning (Okita, 2012), suggesting that explaining information from the L2D training with others might have supported the retention of knowledge, skills, and behavior.

Relationships among news media literacy competencies. We had expected to find that higher scores on news media system knowledge would be positively correlated with higher scores on both the objective and disinformation news media assessments. The strongest relationship in both groups was between disinformation news analysis and news media knowledge; those with higher scores on one tended to have higher scores on the other. This tracks with the finding that news media knowledge and more mindful thinking are both characteristics of high news literate individuals (Maksl, Ashley \& Craft, 2015). We hypothesize that news media knowledge - understanding who owns media outlets and how ownership may influence news content production-may mediate the relationship between media locus of

\footnotetext{
${ }^{7}$ By training instructors who then engaged their networks in their workplaces and community, it is possible that participants were able to reinforce the learning from the training after it ended. However, this is speculative given the lack of information about whether participants shared news literacy-related experiences with one another.
} 
control and disinformation analysis skill. By gaining knowledge about the structures through which news is generated, the necessity for disinformation news analysis skills becomes clear. At the same time, a sense of control over choices about media consumption might be enhanced by a greater understanding of the structures through which news is generated. Additional research is needed to explore this change process and to understand it as a developmental progression of skills and understanding.

The role of media locus of control. We hypothesized that by gaining skills about how to analyze news media and knowledge about how disinformation and manipulation works, L2D participants would have also developed confidence in their skills and understanding and therefore feel more in control of how the media influences them. Media locus of control was slightly higher overall for the L2D group, as well as positively correlated with disinformation news media analysis, news media system knowledge scores, and news cross-checking behavior. In particular, L2D participants rated themselves higher in the three areas of media locus of control that related to taking practical action to gain a greater sense of control over influence from the news media. This finding is consistent with those of Maksl et al. (2017) whose results showed that media locus of control scores for news media literacy program participants were higher despite the lack of an explicit focus on this topic during training. The L2D training focused on behavior change and taught participants how to recognize markers of disinformation and fact-check news stories. Thus, it is not surprising that L2D participants had higher scores than the control group on the media locus of control items related to "doing something about it" when misinformed by the news and paying attention to multiple sources of information to avoid being misinformed. It may be that without news media literacy training, people feel a false sense of control over how they are influenced by the media. This could explain why there were not larger differences between L2D participants and the control group.

The overall MLOC results that did not find a significant difference between the L2D and control group contrast with the results from Maksl et al. (2017) which showed that media locus of control scores for news media literacy program participants were higher despite the lack of an explicit focus on this topic during training. They are consistent with those of Vraga et al. (2015) which found that MLOC did not find significant differences with news media knowledge or current events knowledge, but did see a negative correlation between media skepticism. Further research that assesses media locus of control before and after a media literacy course would provide additional information to the research base on which factors improve participants' media locus of control.

Trust vs. skepticism. Developing skills to discern disinformation tactics, knowledge of types of propaganda, types of media, media owners in Ukraine, and awareness of the potential effects of media ownership on what news is presented may have increased participants' skepticism of news media in general, even as it gave them greater confidence in their own ability to distinguish true news from false news. Additional measures related to trust and healthy skepticism may be needed to explore the relationships among trust, media literacy, and media locus of control.

Demographic differences. Our interpretation of the finding that individuals in 31-55 age group, those who live in the Central region, and those who had completed higher education tended to have higher disinformation news media analysis and news media system knowledge scores, regardless of whether or not they had participated in the L2D training, was that these demographic groups were more likely to be more media literate. Higher education supports the ability to critically assess and evaluate information, just as living in Ukraine's capital Kyiv, the 
most populous city in the Central region and being in an age group with more access to resources and social networks would also support critical thinking and more access to news literate individuals.

Limitations of the study. The finding that L2D participants tended to be somewhat overcritical of the more objective news article raises concerns that the article used for the assessment was not the best choice or differentiator. Though the L2D Ukraine staff believes that the article uses neutral language but covers a somewhat controversial topic that may create an emotional response, the team acknowledged that it can be difficult to find an article that completely aligns with high journalistic standards.

One validity issue concerns the timing of the impact study nearly two years following the L2D trainings. The validity of the L2D media literacy assessment would be enhanced if this measure could be used before and immediately after the trainings to more directly attribute the media literacy skills and knowledge to the L2D training. Implementing this assessment for an L2D and control group at the time of implementing the training would improve its validity and help ensure that the items on the assessment accurately represent the material covered in the training. It could then be used later to determine if media literacy skills and knowledge are retained over time. This is an important consideration for future iterations of any media literacy training.

Finally, L2D program records did not allow the fidelity of the intervention to be evaluated or included in the analysis as a control variable. Given that the citizen trainers engaged their social networks and were not monitored, some may have spent different amounts of time on the training overall or on different parts of it. However, if some participants did not receive the full training, their assessment scores would be weaker than those who did. This limitation would not call the overall findings into question, though it could have weakened the magnitude of the program effects.

\section{IMPLICATIONS FOR PRACTICE AND DIRECTIONS FOR FUTURE INQUIRY}

The L2D impact evaluation shows that participants are better equipped to identify disinformation than more objective news, which suggests that future iterations of the program may need to address how to identify quality journalism and compare it with disinformation to calibrate healthy skepticism and alleviate concerns that the program may lead to blanket distrust of all news media.

The L2D media literacy assessment makes a unique contribution to other efforts to apply media literacy and news media literacy research to a more nuanced form of news media literacy skill in the disinformation age. In addition to demonstrating that L2D participants appear to retain news media literacy skills after 1.5 years, the study also provided evidence that participants can identify disinformation better than the general population and know more about the news media environment than the general population. Most importantly, news media knowledge likely interacts with their news media literacy skills to enable them to more critically engage with news media messages and disinformation.

When adults learn how to analyze news media and gain knowledge about how disinformation and manipulation work, they gain confidence in their skills and understanding and therefore feel more in control of how they are influenced by media. Furthermore, gaining skills and knowledge leads to increased skepticism of news media in general, even as it results in 
greater confidence in the ability to distinguish true news from false news. Greater skepticism and yet greater confidence may temporarily lead to over-application of media analysis skills but it is likely that this can be corrected over time with additional learning and support. Finally, media locus of control may be more accurately measured through retrospective assessment because of lack of awareness of what it takes to critically consume media.

More research is needed to examine media analysis skills in evaluating high and lowquality news content and media skepticism differences, in particular if a media literacy curriculum that, in addition to discussing the news media environment and business, also emphasizes the importance the media plays for an engaged and informed citizenry as Mihailidis (2009) describes (see also, Kahne \& Bowyer, 2017).

\section{REFERENCES}

Arke, E. T., \& Primack, B. A. (2009). Quantifying media literacy: Development, reliability, and validity of a new measure. Educational Media International, 46(1), 53-65.

Ashley, S., Poepsel, M., \& Willis, E. (2010). Media literacy and news credibility: Does knowledge of media ownership increase skepticism in news consumers? Journal of Media Literacy Education, 2(1), 37-46.

Aufderheide, P. \& Firestone, C. (1993). Media literacy: A report of the national leadership conference on media literacy. Aspen Institute; Queenstown, MD.

Fleming, J. (2014). Media literacy, news literacy, or news appreciation? A case study of the news literacy program at Stony Brook University. Journalism \& Mass Communication Educator, 69(2), 146-165.

Garrison, D. R. (1992). Critical thinking and self-directed learning in adult education: An analysis of responsibility and control issues. Adult education quarterly, 42(3), 136-148.

Gorrall, B., Curtis, J., Little, T., \& Panko, P. (2016). Innovations in measurement: Visual analog scales and retrospective pretest self-report designs. Actualidades en Psicología, 30(120), 2-7.

Hobbs, R \& Frost, R. (2003). Measuring the acquisition of media-literacy skills. Reading Research Quarterly, 38, 330-352.

IREX. (2018). Winning the war on state-sponsored propaganda Gains in the ability to detect disinformation a year and a half after completing a Ukrainian news media literacy program. Retrieved from https://www.irex.org/sites/default/files/node/resource/impactstudy-media-literacy-ukraine.pdf

IREX. (2016). Citizen media literacy trainer's guide. Unpublished internal document.

Kahne, J., \& Bowyer, B. (2017). Educating for democracy in a partisan age: Confronting the challenges of motivated reasoning and misinformation. American Educational Research Journal, 54(1), 3-34.

Maksl, A., Ashley, S., \& Craft, S. (2015). Measuring news media literacy. Journal of Media Literacy Education, 6(3), 29-45.

Maksl, A., Craft, S., Ashley, S., \& Miller, D. (2017). The usefulness of a news media literacy measure in evaluating a news literacy curriculum. Journalism \& Mass Communication Educator, 72(2), 228-241.

Mascolo, M. F., \& Fischer, K. W. (2010). The dynamic development of thinking, feeling, and acting over the life span. In W. F. Overton (Ed.), Biology, cognition and methods across 
the life-span. Volume 1 of the Handbook of life-span development, Editor-in-chief: R. M. Lerner. Hoboken, NJ: Wiley.

Masterman, L. (1985). Teaching the media. London: Routledge.

Mesaris, P. (1994). Visual literacy: Image, mind and reality. Boulder, CO: Westview Press.

Mihailidis, P. (2009). Beyond cynicism: Media education and civic learning outcomes in the university. International Journal of Media and Learning, 1(3), 1-13.

Nimmo, B. (2015). Anatomy of an info-war: how Russia's propaganda machine works, and how to counter it. Central European Policy Institute. Retrieved from: http://www.cepolicy.org/sites/cepolicy.org/files/attachments/ben_nimmo.pdf

Okita, S. Y. (2012). Social interactions and learning. In N. M. Seel (Ed.) Encyclopedia of the Science of Learning (pp. 3104-3107). Springer, US.

Potter, W. J. (2004). Theory of media literacy: A cognitive approach. Thousand Oaks, CA: SAGE.

Sucala, M. (2018). Social networks as influencers of health behavior change. Retrieved from https://blogs.ucl.ac.uk/cbc-digi-hub-blog/2018/02/28/social-networks-as-influencers-ofhealth-behavior-change.

Weber, C. (2012). News literacy assessment (Report prepared for The Center for News Literacy). Retrieved from http://drc.centerfornewsliteracy.org/sites/default/files/resourcefiles/2012assessment.pdfMurrock JMLE 10.222 - 41 templated.docx

Vraga, E. K., Tully, M., Kotcher, J. E., Smithson, A.-B., \& Broeckelman-Post, M. (2015). A multidimensional approach to measuring news media literacy. Journal of Media Literacy Education, 7, 41-53.

Zakem, V. (2017). How Russia's Disinformation Campaign Could Extend Its Tentacles. National Public Radio. Retrieved from: http://www.npr.org/2017/01/06/508032496/howrussias-disinformation-campaign-could-extend-its-tentacles 


\section{Appendix A}

\section{Assessment Sources Used to Validate L2D Instrument}

\begin{tabular}{|c|c|c|}
\hline ASSESSMENT & SOURCE & VALIDATION \\
\hline \multirow[t]{4}{*}{ New Media Analysis } & $\begin{array}{l}\text { Arke, E. T., \& Primack, B. A. } \\
\text { (2009). Quantifying media } \\
\text { literacy: Development, } \\
\text { reliability, and validity of a } \\
\text { new measure. Educational } \\
\text { Media International, 46(1), } \\
\text { 53-65. }\end{array}$ & $\begin{array}{l}\text { Developed a media literacy study to establish } \\
\text { construct validity with a critical thinking measure } \\
\text { (California Critical Thinking Skills Test }- \text { CCTST) } \\
\text { and validated it with college students ( } \mathrm{n}=34 \text { ) finding } \\
\text { significant correlation between the two measures ( } \mathrm{r}= \\
\text { 0.32, } \mathrm{p}<.05 \text { ). } \\
\text { The media literacy scale consisted of seven items } \\
\text { grounded in the five domains of Arke and Primack's } \\
\text { conceptual framework to understand, analyze, } \\
\text { evaluate media content. Factor analysis of: } \\
\text { - Objective information } \\
\text { - Purpose of media } \\
\text { - Who is the sender } \\
\text { - That points of view are missing } \\
\text { - Evaluation (What attitudes or feelings are } \\
\text { - Infer left with afterwards?) } \\
\text { suggest?) }\end{array}$ \\
\hline & $\begin{array}{l}\text { Hobbs, R \& Frost, R. (2003). } \\
\text { Measuring the acquisition of } \\
\text { media-literacy skills. Reading } \\
\text { Research Quarterly, 38, 330- } \\
352 .\end{array}$ & $\begin{array}{l}5 \text { open-ended media literacy assessment questions. } \\
\text { Used ANCOVA to compare pre- and post-test, } \\
\text { significant differences in: } \\
\text { - } \text { ability to identify construction techniques, } \\
\text { - } \quad \text { ooint of view, } \\
\text { - } \text { and } \\
\text { - } \text { message purpose } \\
\text { conitive correlation between identifying } \\
\text { comprehension techniques and reading } \\
\end{array}$ \\
\hline & $\begin{array}{l}\text { Source Credibility Scale } \\
\text { developed by Ashley, Poepsel, } \\
\& \text { Willis }(2010)\end{array}$ & \\
\hline & $\begin{array}{l}\text { Weber, C. (2012). News } \\
\text { literacy assessment (Report } \\
\text { prepared for The Center for } \\
\text { News Literacy). Retrieved } \\
\text { from } \\
\text { ttp://drc.centerfornewsliteracy. } \\
\text { org/sites/default/files/resource } \\
\text {-files/2012assessment.pdf }\end{array}$ & $\begin{array}{l}\text { Comparing waves I and II, news literacy students } \\
\text { appropriately rate the evidence as strong and the } \\
\text { story as fair in the reliable source condition. } \\
\text { However, these effects dissipated in the wave III } \\
\text { data } \\
\text { Statistical tests were not conducted in this study. }\end{array}$ \\
\hline
\end{tabular}


E. Murrock, J. Amulya, M. Druckman and T. Liubyva | Journal of Media Literacy Education 2018 10(2), XX-XX

\begin{tabular}{|c|c|c|}
\hline $\begin{array}{l}\text { News Media } \\
\text { Knowledge }\end{array}$ & $\begin{array}{l}\text { Maksl, A., Ashley, S., \& } \\
\text { Craft, S. (2015). Measuring } \\
\text { news media literacy. Journal } \\
\text { of Media Literacy Education, } \\
\text { 6(3), 29-45. }\end{array}$ & $\begin{array}{l}\text { Groups were clustered into high news media literate } \\
\text { and low news media literate groups. } \\
\text { The second hypothesis predicted that highly news } \\
\text { media literate teens would be more skeptical of the } \\
\text { news media than those in the low news media } \\
\text { literacy group. The ANCOVA for high versus low } \\
\text { news media literacy grouping on intrinsic } \\
\text { motivation, controlling for demographic variables, } \\
\text { was statistically significant. The study did not report } \\
\text { out specifically on MLOC or news media knowledge } \\
\text { structures as they were considered dependent } \\
\text { variables. }\end{array}$ \\
\hline $\begin{array}{l}\text { Media Locus of } \\
\text { Control }\end{array}$ & $\begin{array}{l}\text { Maksl et al.'s adaptation of } \\
\text { Wallston \& Studler Wallston's } \\
1978 \text { health locus of control } \\
\text { Maksl, A., Ashley, S., \& } \\
\text { Craft, S. (2015). Measuring } \\
\text { news media literacy. Journal } \\
\text { of Media Literacy Education, } \\
6(3), 29-45 .\end{array}$ & $\begin{array}{l}\text { The study did not report out specifically on MLOC } \\
\text { or news media knowledge structures as they were } \\
\text { considered dependent variables (Automatic vs. } \\
\text { Mindful Thought Processing, MLOC and News } \\
\text { Media Knowledge Structures scores were combined } \\
\text { to create one score per participant, then scores were } \\
\text { clustered into either low or high media literacy). }\end{array}$ \\
\hline
\end{tabular}




\section{Appendix B \\ L2D Impact Evaluation Survey}

We invite you to participate in the survey devoted to knowledge of media and attitudes towards it. It takes 25-30 minutes to fill out the questionnaire. Please complete the survey on your own, do not consult with other people. Please be sincere when answering the questions. All answers are anonymous and will be analyzed in aggregated form. Please fill in the survey by 11 October.

Please fill in survey in one session - do not close tab/ browser until you click "Submit" button. Thank you.

\section{Section 1: Demographic information}

Email Address

Gender

Your age

In what oblast do you live most time during the past 2

years?

Education

Occupation

\section{Section 2: Media analysis: Objective}

Please answer a set of questions for two

articles. Please answer what you feel, without looking for additional information in web. Please be attentive when reading the articles and questions.

Who is the intended audience for this story?

$$
\text { [open-ended] }
$$

Adult population of Ukraine who are closely following the news

The wording of the message suggests certain conclusions *

- Yes

- No

- Don't know

What kind of emotion does this message evoke? Select all that apply.

- Positive

- Neutral

- Negative

- Don't know

What is the purpose of this article? [Select one response]

- To inform about what happened

- To convince and influence readers

- I do not know

Does the article miss any sides/points of view?

Yes --> What sides/points of view?

[Open-ended question]

- Speaker of Russian State Border Service

- No
The message uses terms that are easy to understand. [Select one response]

- Yes

- No

- Don’t know

The title of the article appeals to emotions. [Select one response]

- Yes

- No

- Don’t know

The reporter... [Select one response]

- shows bias in what he/she says

- His/her position is neutral

- Don't know

The article is balanced in terms of opinions, references, and sources. [Select one response]

- Yes

- No

- Don't know

Are facts separated from opinion? [Select one response]

- Yes

- No

- Don't know

How credible are the statements made by Oleg Slobodyan, the individual cited in the story? [Select one response]

1-10 scale where 1 - Not credible at all, and 10 Extremely credible

The article has an explicit news hook. [Select one response]

- Yes

- No

- Maybe

- Don't know

The statements in this article were supported by facts. [Select one response] 
- Yes

- No

Rate the following statement: "this is an objective story." (In this definition, objective means "balanced, unbiased"). [Select one response]

Strongly disagree

Disagree

Neither agree nor disagree

Agree

Strongly agree

Considering your answers above, how would you rate the story? [Select one response]

1 - It is not credible

10 - It is credible

\section{Section 2: Media analysis:}

Disinformation

Who is the intended audience for this story? [Openended

question]

- Russian-speaking population in Ukraine and abroad, ethnic minorities in Ukraine

The wording of the message suggests certain conclusions *

- Yes

- No

- Don't know

What kind of emotion does this message evoke?

Select all that apply.

- Positive

- Neutral

- Negative

- Don't know

What is the purpose of this article? [Select one response]

- To inform about what happened

- To convince and influence readers

- I do not know

The goal of the message is to impose opinions or rouse the viewer to action. [Select one response]

- Yes

- No

- Don’t know

Did the article miss any points of view?
- Yes

- No

- Don't know

What points of view may be missing? [Open-ended question]

- Ukrainian officials or direct sources from Ministry of Education

All names of officials, data and quotes/opinions have clear references. [Select one response]

- Yes

- No

- Don’t know

The style, images, statistics, and symbols correspond to the content of the message. [Select one response]

- Yes

- No

- Don't know

The title of the article... [Select one response]

- is neutral

- provokes an emotional response

- Don’t know

The title of the article... [Select one response]

- Corresponds to the content of the article

- Doesn't correspond to the content of the article

The reporter... [Select one response]

- shows bias in what he/she says.

- His/her position is neutral

- Don't know

Are facts separated from opinion? [Select one response]

- Yes

- No

- Don’t Know

The article is balanced in terms of opinions, references and sources. [Select one response]

- Yes

- No

- Don't know

How credible are the statements made by the experts cited in the article? [Select one response]

1-10 Scale, where 1 -Not credible at all, and 10 Extremely credible 
The article has an explicit news hook. [Select one response]

- Yes

- No

- Maybe

- Don't know

Multiple political figures are mentioned.

[Select one

response]

- Yes

- No

- Maybe

- Don't know

It focuses on achievements/activities of one person.

[Select one response]

- Yes

- No

- Don't know

The statements in this article were supported by facts.

[Select one response]

- Yes

- No

- Do not know

Rate the following statement: "this is an objective story." (In this definition, objective means "balanced, unbiased"). [Select one response]

- Strongly disagree

- Disagree

- Neither agree nor disagree

- Agree

- Strongly agree

Considering your answers above, how would you rate the story? [Select one response]

1 - It is not credible, 10 -It is credible

\section{Section 3: News Media Knowledge}

1. Most media outlets in the Ukraine are * One answer

[Institutions that produce news - media ownership]

- owned by oligarchs +1

- owned by the government

- businesses

- independent

- do not know

To which private owner do the following channels belong to? One answer in each row [Institutions that produce news - media ownership]
R.Akhmetov

I.Kolomoyskiy

V.Pinchuk

P.Poroshenko

D.Firtash

Do not know

$+1$

5th channel

Inter

STB

Kanal Ukrayina

Please select all characteristics that propaganda has as opposed to news and/or information. [Select all that apply]

[Propaganda vs. news - L2D curriculum]

- Presents partial, incomplete information +1

- Appeals to emotions +1

- Appeals to well-known facts

- Purpose is to communicate

- Purpose is to impose +1

- Provides knowledge

- Has objectivity

- Influences opinions +1

- Purpose is to inform and explain but not to offer solutions

- Purpose is to inform and explain but also to convince +1

- All from above

- Do not know

When it comes to reporting the news, the main difference between a website like and a website like Ukrayinska Pravda is that [How news content is produced - news outlet vs. aggregator]

- Ukr.net does not have reporters who gather information, while Ukrayinska Pravda does +1

- Ukr.net focuses on national news, while Ukrayinska Pravda focuses on local news

- Ukrayinska Pravda has more editors than ukr.net does

- Do not know

Who has THE MOST influence on what gets aired on the national TV news? One answer

[How news content is produced - influence of ownership]

- Individual reporters

- The anchor, the person reading the news

- The cameraman

- The owner +1

- The editor

- Do not know 
In the news journalistic standards are violated if...

Select all that apply

[Journalistic standards - L2D curriculum]

- The expert's opinion is presented as an explanation of the situation from the stance of one party +1

- The expert's opinion is used as a point of commentary or an assessment of the further development of the event at hand.

- There is no answer to the question: Where? +1

- There is no answer to the question: When? +1

- There is no answer to the question: Who is protagonist of the story?

- Generalized reference to opinions +1

- Do not know

"The control by the state, organizations, or other groups of people over the public expression of information, thoughts, or creativity." This is the definition of which concept? [Select one response]

[Censorship definition -L2D curriculum]

- Advertisement

- Manipulation

- Propaganda

- Censorship +1

- Self-censorship

- Dzhynsa

- Fake News

- None

- Do not know

"Paid or sponsored reporting. The material with no explicit news hook." Definition of what is it? [Select one response]

[Advertorial definition -L2D curriculum]

- Advertisement

- Manipulation

- Propaganda

- Censorship +1

- Self-censorship

- Dzhynsa

- Fake News

- None

- Do not know

What of the following can be used as markers of fakes on TV? Select all that apply

[Characteristics of manipulation in news -

L2D curriculum]

- Incredible and stunning situations referred to in the stories +1

- Dramatization by journalists (use of emotional vocabulary) +1

- There are names of organizations, cities and persons that you did not know before
- Journalist put his/ her opinion in the story +1

- Journalist leads (with questions or tone, for example) interviewees and other key individuals in the story to certain judgments +1

- Video/ picture is not commented by reporter

- Inconsistency of the video/ picture with reporter's words +1

- Trusted TV channels don't produce fake news

- It is impossible to identify fake news

- If story is aired during regular news hours then it is true

- It is a breaking story

- Journalist is emotional when reporting about the story

- I have heard it from different sources

- I do not know

What would you check first in social networks if you suspect that post is fake? Select all that apply [If and how news is cross-checked -L2D curriculum]

- Number of shares of the post

- Number of comments to the post

- Account where information is spread +1

- If post contains a picture or not

- I will check if my friends are sharing it as well

- Checking the website from which the post originated

$+1$

- If everyone is sharing it, it must be true

- I don't care about checking and just ignore it

- I will read it carefully

- All from above

- I do not know

\section{Section 4: Trust}

If you heard about something important to you happening, where would you go first to try and find out if it were true? [Select one response]

- Consult with my friends on their opinion

- I will cross check from multiple sources

- Nothing - I wouldn't try to find out if it were true

- Don't know

Remembering that this is an anonymous survey and no one is judging, do you trust any sources?

Yes: Which ones? Please

list

No: Then why do you watch

news?

Are you aware of sponsored/ "paid for" materials in the media, as well as hidden advertising presented in the form of news? [Select one response]

- Yes

- No

- Maybe 
Is the issue of sponsored/ "paid for" materials in the media important for you? [Select one response]

- Very important

- Rather important

- Rather not important

- Not important

- Hard to say

- Don't know

Indicate the degree to which you agree with this statement "The ownership of TV is important to me" [Select one response]

- Very important

- Rather important

- Rather not important

- Not important

- Hard to say

- Don't know

How often do you come across Dzhynsa when you read or watch news?

Almost in every material

About in half of materials

Significantly less than in half of materials

Never

do not know what dzhynsa is

\section{Section 5: Media locus of control}

If I am misinformed by the news media, it is my own behavior that determines how soon I will learn credible information.

I am in control of the information I get from the news media.

When I am misinformed by the news media, I am to blame

The main thing that affects my knowledge about the world is what I myself do.

If I pay attention to different sources of news, I can avoid being misinformed.

If I take the right actions, I can stay informed.

\section{Section 6: (Sorts treatment and control group)}

Did you take part in training on media literacy during winter 2015-2016?

Yes

No

\section{Section 7: follow-up questions (L2D participants} only)

If answer "Yes" to G1. For how long did the training last?

- Up to 1,5 hour

- 2-4 hours
- 5-8 hours

- More than 8 hours

- I do not remember

Did you conduct trainings on media literacy yourself?

- Yes

- No

How much were you sure that you were able to analyze the truthfulness of the media content (content of news on television, radio, in the press or on the Internet) BEFORE the training? Please try to remember your attitudes and behavior before the training on media literacy and compare what you do now.

Before the training

Almost always

Sometimes

Very rarely, only when I doubt the news

Never additionally check

Now

Almost always

Sometimes

Very rarely, only when I doubt the news

Never additionally check

How much are you sure that you are able to analyze the truthfulness of the media content (content of news on television, radio, in the press or on the Internet) now?

$1-10$ scale where 1 is not sure at all, and 10 is completely confident

How would you evaluate your knowledge / skills about how to distinguish true news from false ones BEFORE the training?

$1-10$ scale where 1 is very bad, and 10 is very good

How would you evaluate your knowledge / skills about how to distinguish true news from false ones now?

$1-10$ scale where 1 is very bad, and 10 is very good

How confident are you in analyzing the truthfulness of media content

Before the training

Very confident

Confident

Neutral

Not confident

Not confident at all 
Now

Very confident

Confident

Neutral

Not confident

Not confident at all

Do you agree with the following statements?

BEFORE the training I cross-checked the news when I had doubts about the content

Definitely did

Probably did

Might or might not have

Probably did not

Definitely did not

Now the training I cross-check the news when I have doubts about the content

\author{
Always do \\ Very often \\ Sometimes \\ Rarely \\ Never
}

Hoe many people (friends, relatives, colleagues) did you transfer the knowledge/skills received in the media literacy program?

- No one

- 1-5 people

- 6-10 people

- 11-20 people

- More than 20 people 
E. Murrock, J. Amulya, M. Druckman and T. Liubyva | Journal of Media Literacy Education 2018 10(2), 53 - 85

\title{
Реформа образования и зачистка языков нацменьшинств
}

\author{
Тема: D Рефьорма образования: необратимые поспедствия (153) \\ 17:58 12.09 .2017 (oCmoaneno: 10:15 13.09.2017) O 1005 b 12 p 9
}

Украинизация стала сюрпризом реформы образования. Отныне предметы на языках нацменьшинств будут вестись лишь в начальной школе и то до 2020 года. В Украине и мире забили тревогу: это нарушает права нацменьшинств, которые составляют треть населения страны.

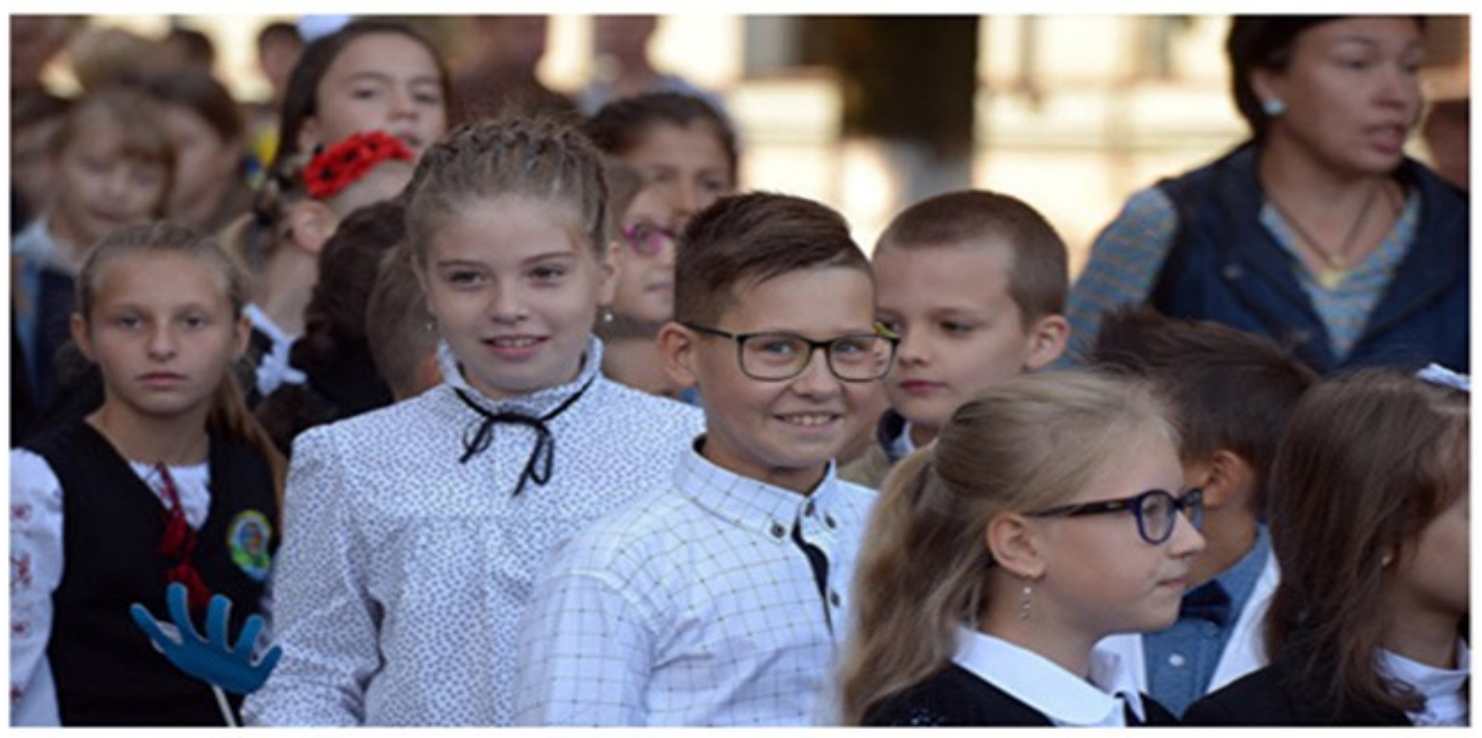

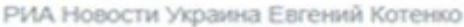

\section{Соня Тарасюк, РИА Новости Украина}

\section{Скандальная реформа}

Тотальная украинизация стала главный сюрпризом реформы образования, которая, похоже, рискует усилить противостояние не только внутри общества, но и между Украиной и другими странами.

Как известно, во вторник, 5 сентября, в Украине таки стартовала долгожданная ресрорма образования. В первый пленарный день новой сессии депутаты приняли во втором чтении закон "Об образовании" (№3491-д).

Однако документ сразу же вызвал немало противоречий. В частности, зерном раздора стала 7 норма закона о том, что с 1 сентября 2018 года в Украине преподавание на языке национальных меньшинств, к которым относится и русский, будет разрешено только для учеников младшей школы. 
E. Murrock, J. Amulya, M. Druckman and T. Liubyva | Journal of Media Literacy Education 2018 10(2), 53 - 85

\author{
Objective Reporting Artifact Sample
}

\title{
Перестрелка на границе: боевики прорывались из России
}
(1) 2 часа назад
f $\nabla<$ П поделиться

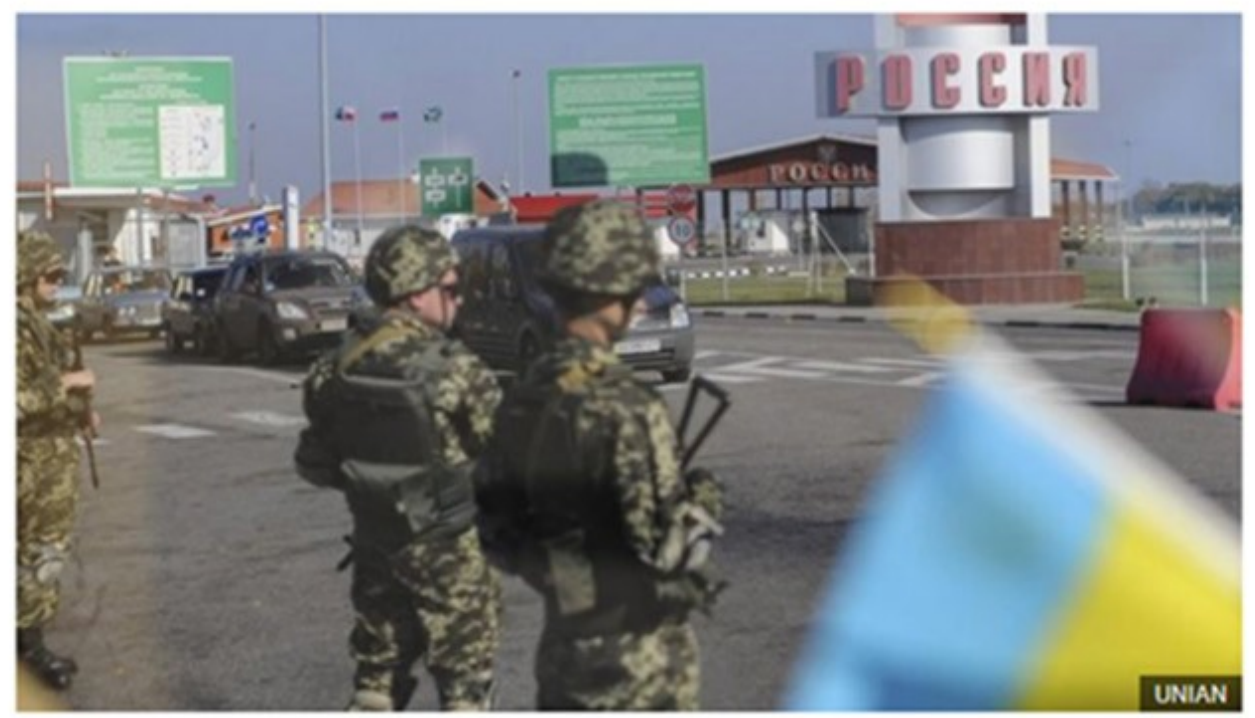

Российский пограничник погиб при задержании двух человек, которые прорывались из РФ в Украину. Одного из них задержали, другой подорвался. Об этом сообщили в ФСБ.

Инцидент произошел еще 30 сентября. В ФСБ прокомментировали его только сейчас. По данным российских спецслужб, двое неизвестных пытались незаконно проникнуть с территории России в Украину вне пункта пропуска. Ранее российские СМИ сообщали, что боевики пришли из Украины.

Инцидент произошел в пограничной зоне в селе Теткино Курской области. У двух мужчин проверяли документы, они начали сопротивляться.

"Во время столкновения один из них совершил самоподрыв, второй задержан", - заявили в ФСБ. Об их мотивах не сообщается.

Российский пограничник скончался от полученных огнестрельных ранений.

В России из-за этого инцидента открыли уголовное дело.

Ранее российские СМИ сообщали, что нападавшие пришли с территории Украины, и что таким образом они возвращались из Сирии в одну из российских северокавказских республик.

О том, что боевики не пересекали украинскую границу, заявлял спикер украинской Госпогранслужбы Олег Слободян. По словам Слободяна, по неподтвержденным данным, злоумышленники были выходцами с Кавказа, а нарушений правил пересечения границы на этом участке в тот день зафиксировано не было. 